\title{
Co-Streptavidin Precipitation
}

Saïda Dadi, Dominique Payet-Bornet and Pierre Ferrier ${ }^{*}$

Centre d'Immunology de Marseille Luminy (CIML), Aix-Marseille UM2, INSERM UMR1104, CNRS UMR7280, Marseille, France

*For correspondence: ferrier@ciml.univ-mrs.fr

[Abstract] Co-Streptavidin Precipitation (Co-SP) is a method to pull down protein partners of a protein of interest tagged with the streptavidin binding protein domain, and using streptavidin columns that specifically bind to Streptavidin Binding Protein (SBP) in order to test the proteinprotein interactions. Proteins of interest to be tested for their interaction are artificially coexpressed in "easy to transfect" cells. Pull down proteins can be analyzed by western blot for suspected protein partner.

\section{Materials and Reagents}

1. HeLa cells (ATCC, catalog number: CCL-2)

2. SBP-Calmodulin Tag Expression Vector pNTAP (Inter Play N-Terminal Mammalian TAP Vector, Agilent Technologies-Stratagene, catalog number: 240101)

3. Lipofectamine (Life Technologies, Invitrogen ${ }^{\mathrm{TM}}$, catalog number: 11668-027)

4. Fugene 6 (F. Hoffmann-La Roche, catalog number: 05061377001)

5. FLAG tag Expression Vector pCMV-Tag2 (Agilent Technologies-Stratagene, catalog number: 211172)

6. NP40

7. Steptavidin agarose beads (Sigma-Aldrich, catalog number: S-1638)

8. Anti- Calmodulin antibody (Upstate, catalog number: 07-482)

9. Anti- Flag antibody (Sigma-Aldrich, catalog number: F1804-200UG)

10. Protease inhibitor cocktail, EDTA free(F. Hoffmann-La Roche, catalog number: 04693159001)

11. DNase I (Sigma-Aldrich, catalog number: DN25)

12. Benzonase nuclease (Sigma-Aldrich, catalog number: E1014)

13. Laemmli loading buffer (see Recipes)

14. Sucrose buffer (see Recipes)

15. Nuclei Lysis buffer for hard to extract nuclear factors (see Recipes)

16. Nuclei Lysis buffer for soluble nuclear factors (see Recipes) 


\section{Equipment}

1. Wheel in a cold room

2. Refrigerating centrifuge $1.5 \mathrm{ml}$ tubes

\section{Procedures}

A. Cell transfection

1. Co-transfected 10 to $50 \times 10^{6}$ of HeLa cells (or other "easy to transfect cells") with your gene of interest "1"-FLAG cloned into pCMV-Tag2 expression vector, and your gene of interest "2"-SBP-Calmodulin cloned into pNTAP, or the empty expression vector pNTAP as a control. Transfection is performed with standard transfection protocols (such as Lipofectamine, Invitrogen or Fugene 6, Roche or Calcium Chloride precipitation).

B. Nuclear extract preparation (also see Dadi et al., 2013)

24 to $48 \mathrm{H}$ after transfection, the cells are lysed and nuclear extracts were prepared using the nuclear extract lysis protocol:

1. Use trypsin to recover the cells and wash cells with cold $1 \times$ PBS then centrifuge for 6 min at $300 \times g$ at $4{ }^{\circ} \mathrm{C}$. From now on, all the steps should be performed on ice.

2. Resuspend the cell pellet in the chilled Sucrose buffer $\left(5 \mu \mathrm{l} / 1 \times 10^{6}\right.$ cells).

3. Add vol/vol Sucrose buffer containing $0.5 \%$ NP40 (final concentration $0.25 \%$ ).

4. Mix by pipetting on ice. Save a small aliquot (1 to $5 \%$-aliquot 1 ).

5. Centrifuge $10 \mathrm{~min}$ at $1,100 \times \mathrm{g}$ at $4{ }^{\circ} \mathrm{C}$. The pellet contains the nuclei and looks nacreous to white. The supernatant contains the cytoplasmic protein extract and can be saved if a cytoplasmic protein is of interest for Co-IP. Save a small aliquot (1 to $5 \%$-aliquot 2).

6. Wash the pellet with Sucrose buffer (without NP40) and centrifuge $10 \mathrm{~min}$ at 2,000 rpm at $4{ }^{\circ} \mathrm{C}$.

7. Depending on the nuclear proteins to be purified, you can lyse nuclei with:

a. Either the Nuclei Lysis buffer for soluble proteins ( $5 \mu \mathrm{l} / 1 \times 10^{6}$ cells);

b. Or the Nuclei Lysis buffer for hard-to-extract proteins $\left(5 \mu \mathrm{l} / 1 \times 10^{6}\right.$ cells $)$ and add DNase $5 \mathrm{U} / \mu \mathrm{l}$ and Benzonase $5 \mathrm{U} / \mu \mathrm{l}$. Resuspension is hard since it's very viscous with DNA.

8. Incubate on a wheel at $4{ }^{\circ} \mathrm{C}$ for $45 \mathrm{~min}$ to $1 \mathrm{~h}$. Save a small aliquot (1 to $5 \%$-aliquot 3 ).

9. Centrifuge $3 \mathrm{~min} 10,000 \times g$ at $4{ }^{\circ} \mathrm{C}$. The supernatant is the protein nuclei extract that will serve for the IP. Save a small aliquot from the supernatant (1 to $5 \%$-aliquot 4 ; which is also the input of the IP experiment) and the pellet is the insoluble substance such as 
membrane debris. Resuspend the pellet in $5 \mu \mathrm{l} / 1 \times 10^{6}$ cells of $150 \mathrm{mM} \mathrm{NaCl}, 10 \mathrm{mM}$ Tris. Save a small aliquot (1 to $5 \%$-aliquot 5 ).

10. Verify the efficiency of the lysis by analyzing by SDS-PAGE and western-blot the presence of your proteins of interest in the saved aliquots.

i. Aliquot 1: total cells

ii. Aliquot 2: cytoplasm protein extract

iii. Aliquot 3: total nuclei extract

iv. Aliquot 4: nuclear protein extract

v. Aliquot 5: insoluble nuclei extract

C. Co-streptavidin purification (Refs 2-4)

1. Incubate the protein nuclei extract $2 \mathrm{~h}$ at $4{ }^{\circ} \mathrm{C}$ with $25 \mu \mathrm{l}$ of streptavidin agarose (bead volume). Optimization is required for efficient SP of your SBP-protein of interest and the quantity of streptavidin beads may vary according to the protein stability, etc.

2. Wash 4 to 6 times the beads in $100 \mathrm{mM} \mathrm{NaCl}, 10 \mathrm{mM}$ Tris, $\mathrm{HCl} \mathrm{pH} \mathrm{7.8,} \mathrm{by} \mathrm{mixing} \mathrm{by}$ pipetting and centrifuging 10,000 $\mathrm{xg}$ for $30 \mathrm{sec}$.

3. Elute the bound proteins in Laemmli loading buffer and separate by SDS-PAGE and analyze by western blot using antibodies against Calmodulin and Flag.

\section{$\underline{\text { Recipes }}$}

1. Laemmli buffer

$20 \%$ Glycerol

$4 \%$ SDS

$250 \mathrm{mM}$ Tris (pH 6.8) (stacking buffer for upper gel of SDS PAGE)

1.4 M 2-mercapthoethanol

A pinch of bromophenol blue

2. Sucrose buffer

0.32 M Sucrose

$3 \mathrm{mM} \mathrm{CaCl} 2$

$2 \mathrm{mM} \mathrm{MgOAc}$

$0.1 \mathrm{mM}$ EDTA

$10 \mathrm{mM}$ DTT

$0.5 \mathrm{mM}$ PMSF

3. Nuclei Lysis buffer for hard to extract nuclear factors

$50 \mathrm{mM}$ Hepes (pH 7.8)

$3 \mathrm{mM} \mathrm{MgCl} 2$ 
$300 \mathrm{mM} \mathrm{NaCl}$

$1 \mathrm{mM}$ DTT

$0.1 \mathrm{mM}$ PMSF

Protease inhibitor complete mini EDTA free tablets $1 \mathrm{x}$

4. Nuclei Lysis buffer for soluble nuclear factors

$50 \mathrm{mM}$ Hepes (pH 7.8)

$50 \mathrm{mM} \mathrm{KCl}$

$300 \mathrm{mM} \mathrm{NaCl}$

$0.1 \mathrm{mM}$ EDTA

$10 \%$ Glycerol

$1 \mathrm{mM}$ DTT

$0.1 \mathrm{mM}$ PMSF

Protease inhibitor complete mini EDTA free tablets $1 x$

\section{Notes}

1. The number of cells to be transfected need to be optimized, depending on the size and the stability of the proteins to be expressed.

\section{Acknowledgments}

Work in the PF laboratory is supported by institutional grants from 'Institut National de la Santé et de la Recherche Médicale' (Inserm) and 'Centre National de la Recherche Scientifique' (CNRS), and by dedicated grants from the Commission of the European Communities, the 'Agence Nationale de la Recherche' (ANR), the 'Institut National du Cancer' (INCa), the 'ITMO Cancer Alliance Nationale pour les Sciences de la Vie et de la Santé' (AVIESAN) and the 'Fondation Princesse Grace de la Principauté de Monaco'. S.D. was supported by fellowships from the 'Ministère de l'Enseignement Supérieur et de la Recherche', the 'Fondation pour la Recherche Médicale' (FRM), and the 'Société Française d'Hématologie' (SFH).

\section{References}

1. Dadi, S., Le Noir, S., Payet-Bornet, D., Lhermitte, L., Zacarias-Cabeza, J., Bergeron, J., Villarese, P., Vachez, E., Dik, W. A., Millien, C., Radford, I., Verhoeyen, E., Cosset, F. L., Petit, A., Ifrah, N., Dombret, H., Hermine, O., Spicuglia, S., Langerak, A. W., Macintyre, E. A., Nadel, B., Ferrier, P. and Asnafi, V. (2012). TLX homeodomain oncogenes mediate T 
cell maturation arrest in T-ALL via interaction with ETS1 and suppression of TCRalpha gene expression. Cancer Cell 21(4): 563-576.

2. Dignam, J. D., Lebovitz, R. M. and Roeder, R. G. (1983). Accurate transcription initiation by RNA polymerase II in a soluble extract from isolated mammalian nuclei. Nucleic Acids Res 11(5): 1475-1489.

3. Gersten, D. M. and Marchalonis, J. J. (1978). A rapid, novel method for the solid-phase derivatization of IgG antibodies for immune-affinity chromatography. J Immunol Methods 24(3-4): 305-309.

4. Schneider, C., Newman, R. A., Sutherland, D. R., Asser, U. and Greaves, M. F. (1982). $\underline{A}$ one-step purification of membrane proteins using a high efficiency immunomatrix. $\mathrm{J}$ Biol Chem 257(18): 10766-10769.

5. Simanis, V. and Lane, D. P. (1985). An immunoaffinity purification procedure for SV40 large T antigen. Virology 144(1): 88-100. 